\title{
Influence of climatic Parameters on The Two- spotted Spider Mite population based on Remote Sensing in Southeast of the Caspian Sea
}

Mahmoud Jokar ( $\square$ m.jokar2863@gmail.com )

AREEO: Agricultural Research Education and Extension Organization

\section{Research Article}

Keywords: Evapotranspiration, Spider mite, remote sensing, Sentinel-2\&5

Posted Date: June 18th, 2021

DOl: https://doi.org/10.21203/rs.3.rs-582788/v1

License: (c) (i) This work is licensed under a Creative Commons Attribution 4.0 International License.

Read Full License 


\section{Abstract}

Tetranychus urticae Koch (Acari: Tetranychidae) is a serious pest in cotton fields worldwide. Monitoring of $T$. urticae with time-series of vegetation index and climatic factors based satellite data was applied to near real-time assessing. The current study aimed to determine correlations between $T$. urticae population dynamic and effects of Aerosol index of Sentinel-5, Sentinal-2-NDVI (10m), The Land Surface Temperature (LST), MODIS-Evapotranspiration (ET) and CHIRPS-precipitation. Spider mite out-breaking has coincided with the wheat harvesting and where experienced several dusty days with high aerosol index 0.167. Rainfall had a significant negative correlation with $T$. urticae population $\left(R^{2}=0.378\right)$ and a threshold precipitation level was estimated at least $2 \mathrm{~mm}$ to clean up the canopy. We could not find a significant pattern between temperature and T. urticae population until August 2020 and then the significant positive relationships were observed during August 2020, $R^{2}=0.3519,0.1283,0.1675$ and 0.178 , weekly. Evapotranspiration depicted a statistically synchronous relationship $R^{2}=0.637$ with $T$. urticae dynamism. There was a positive correlation between increasing NDVI and T. urticae population until August 2020 and then was shifted to negative pattern $R^{2}=0.273$ and 0.139 . These findings, aerosol index of sentinel-5 and MODIS-evapotranspiration have potential to forecast spider mite population with high temporal resolution.

\section{Introduction}

Tetranychus urticae Koch, is a serious economic pest in cotton fields worldwide because of polyphagous behavior with a wide range of plant hosts about 900 plant species (Brown et al. 2017). The main spider mite fauna, Tetranychus spp., is consisting of Tetranychus pacificus, Tetranychus turkestani and T. urticae, and known as a comment pest of cotton. T. urticae distribution is extended in all territory of Iran (Golestan, Tehran, Azerbaijan, Khorasan, Ardebil, Fars ) on cotton fields (Honarparvar et al. 2012). Yield loss due to dusty spider mite infestation of cotton, Gossypium hirsutum L., was measured by entomological researchers such as during 2010 and 2011 to determine two-spotted spider mite population and injury ratings (Scott et al. 2013). Among abiotic parameters, climatic parameters play a key role in pest population dynamism especially temperature, relative humidity, rainfall, sunshine hours, etc. The climate factors affected not only mites (Ahmed et al. 2012) but also ticks such as a 14-year population study on Scabies in Taiwan (Liu et al. 2016). Five years of systematic sampling program in Bangladesh was studied the effect of weather parameters on Oligonychus coffeae N. (Acarina: Tetranychidae), Red Spider Mite, and showed positive (temperature, relative humidity, and sunshine hours) and negative response (rainfall and cloud coverage) (Ahmed et al. 2012). Demographic parameters of spider mite pests are temperature-dependent such as the intrinsic rate of increase $\left(r_{m}\right)$ of $T$. pacificus, Eotetranychus willamettei (McGregor) (Acari: Tetranychidae) (Stavrinides and Mills 2011) as well as development time, sex ratio, and fecundity of T. urticae (Margolies and Wrensch 1996). The lifetables of $T$. urticae significantly was influenced by different levels of macronutrient N, P and $\mathrm{K}$ (Wermelinger et al. 1991). Population dynamics of $T$. urticae were seasonally investigated under acaricide constraint on eggplant in Bursa Province, Turkey. T. urticae population was positively and 
negatively responded with mean temperature and mean humidity, respectively (Kumral and Kovanci 2005). According to the targets of the Paris agreement $\left(1.6^{\circ} \mathrm{C}\right.$ warming by 2050), until 2050 for tomato, a suitability modeler based on climate change (CC) which was equipped with irrigation facilities (AEI) predicted unsuitable conditions for tomato production and increasing outbreak risk of two-spotted spider mite globally, because of failure in biological control (Litskas et al. 2019). Therefore, climate conditions would also be affected the pest population dynamic, especially in large-scale projections. Using reflectance spectroscopy in two common ways with satellite or unmanned aerial vehicle (UAV) equipped by multispectral imagery. Diffuse reflectance spectroscopy (Visible/Near Infrared Reflectance Spectroscopy) identified infestation regions by $T$. urticae and also quantitatively assessed $T$. urticae damages in Strawberries (Fraulo et al. 2009). Some researches such as, Reisig and Godfrey (2006), reported that, Aerial and satellite images to distinguish infested cotton by aphid (Aphis gossypii Glover) and spider mite (Tetranychus spp.) from healthy plant. Martin and Latheef, (2017) evaluated a groundbased multispectral optical sensor for detecting spider mite damage in greenhouse condition on cotton production. The supervised classification approaches such as Support Vector Machine (SVM) and a transferred Convolutional Neural Network (CNN) was reported for mite-infestation using UAV multispectral imagery (Huang et al. 2018). Species composition are another GIS and remote sensing approaches applied for modeling ecological niche of Tetranychoid mites (Acari: Tetranychoidea) in in different climates of Tehran Province, Iran (Ghasemi Moghadam et al. 2016). The current study aimed to determine the potential effects of five climate and vegetation characters including air pollution (dust), The Normalized Difference Vegetation Index (NDVI), The Land Surface Temperature (LST), Evapotranspiration (ET) and precipitation on Spider mite population.

\section{Material And Method}

\section{2-1-Study area}

The study area presents unique climatic conditions of northeast of the Caspian Sea including the Hyrcanian forest (southern), desert (northern), fertile lands and vast paddy fields (central areas) where 14 adjacent districts located in the northeast of Iran (Figure 1), with latitude ranging from $36^{\circ} 30^{\prime}$ to $38^{\circ} 10^{\prime} \mathrm{N}$ and longitudes from $53^{\circ} 50^{\prime}$ to $56^{\circ} 20^{\prime} \mathrm{E}$. Climatic diversity of study areas distinguishes the role of climatic effects on hotspot formation of spider mite. The area occupies $21400 \mathrm{~km}^{2}$ approximately, and the altitude oscillates from -39 to 3780 meters above sea level. Average values of annual temperature and precipitation are $16.88^{\circ} \mathrm{C}$ and $454 \mathrm{~mm}$, respectively. In the study area, most of the farmer communities have small landholding and wheat, barley, canola, and broad bean are the most important autumn crops. Soybean, cotton, rice, and sorghum also are the most important summer crops in this province. Golestan province is one of the top three cotton-producing provinces in Iran as it is called the "land of white Gold". Our study has strongly covered all cotton agricultural areas within the Golestan province. The highest area under cotton cultivation belongs to Aqqala (33\%), western part of Gonbad-eQabous (31\%), and Gorgan (10\%), while the crop is barely present in Minoodasht and Maravehtapeh at all. To achieve more accurate data, all satellite images were masked by of The Shuttle Radar Topography 
Mission (SRTM, 30m) (Farr et al. 2007). The mask areas were high-dense forests (Hyrcanian forests) where is not the ecological niche of T. urticae.

\section{2-2-Climate and vegetation datasets (Independent factors):}

\section{2-2-1-Precipitation}

The Climate Hazards Group Infrared Precipitation with Stations (CHIRPS) is one of reliable precipitation dataset which provided globally high resolution of precipitation by interpolation approaches (around a $0.05^{\circ}$ ) for a long period (daily, 1981-present) based on infrared Cold Cloud Duration (CCD), ImageCollection ID on Google Earth Engine (GEE), cloud-based image processing platform, "UCSBCHG/CHIRPS/DAILY", (Funk et al. 2015).

\section{2-2-2-Land Surface Temperature (LST)}

The Terra-MODIS land surface temperature (LST) product (MOD11A1, $1 \mathrm{~km}$, daily) form 09/06/2020 to 17/09/2020 was manipulated by Google Earth Engine (GEE). For all fifteen monitoring windows (Table.1), LST time series provided by mean of LST (day, night) temperature for every window.

Table.1. monitoring windows for synoptic recorded spider-mite population 


\begin{tabular}{|ll|}
\hline monitoring windows & Date range \\
\hline W1 & May 30, 2020 - June 9, 2020 \\
\hline W2 & June 9, 2020- June 17, 2020 \\
\hline W3 & June 17, 2020- June 24, 2020 \\
\hline W4 & June 24, 2020- June 30, 2020 \\
\hline W5 & June 30, 2020- July 8, 2020 \\
\hline W6 & July 8,2020 - July 15, 2020 \\
\hline W7 & July 15, 2020- July 21, 2020 \\
\hline W8 & July 21, 2020- July 29, 2020 \\
\hline W9 & July 29, 2020-August 3, 2020 \\
\hline W10 & August 3, 2020- August 11, 2020 \\
\hline W11 & August 11, 2020- August 18, 2020 \\
\hline W12 & August 18, 2020- August 29, 2020 \\
\hline W13 & August 29, 2020- September 5, 2020 \\
\hline W14 & September 5, 2020- September 10, 2020 \\
\hline W15 & September 10, 2020- September 17, 2020 \\
\hline
\end{tabular}

\section{2-2-3-Evapotranspiration (ET)}

Net Evapotranspiration was provided by The MOD16A2/V6 product, Evapotranspiration/Latent Heat Flux, is an 8-Day Global $500 \mathrm{~m}$. The algorithm was embedding the MOD16 data collection is based on PenmanMonteith equation (Allen 1996), which combination of different input sources including daily meteorological reanalysis data, vegetation property, albedo, and MODIS-land cover.

\section{2-2-4-The Normalized Difference Vegetation Index (NDVI)}

Normalized Difference Vegetation Index (NDVI) is one of the most applicable vegetation indexes in remote sensing projection (Lamqadem et al. 2018). NDVI is worked on the red and NIR reflectance of soil. The NDVI values are in range from -1 (water resources and snow body) to +1 (full vegetation coverage). In the current research, a 7-10-day multi-temporal Sentinal-2 was provided NDVI index during monitoring windows.

\section{2-2-5-Air pollution (aerosol index)}

The "NRTI/L3_AER_Al" dataset from Sentinel-5 provides near real-time high-resolution imagery of the UV Aerosol Index (UVAl or AAL). This index is worked according to wavelength-dependent changes in 
Rayleigh scattering in the UV spectral range for a pair of wavelengths (at the $354 \mathrm{~nm}$ and $388 \mathrm{~nm}$ ). The positive AAI indicates the presence of phenomena which can absorb UV like dust and smoke. The pair of selected wavelengths have been absorbed very low by ozone (Soleimany et al. 2021).

\section{2-3- spider-mite sampling and spatial analysis for T. urticae distribution map (Dependent Factor)}

\section{2-3-1- spider mite sampling as ground truth data}

Ground-truth data of spider-mite population was reported by mean percentage of leaf area which were infected with various types of spider mite symptoms (dust-silk webbing, yellow spots, etc.). 100 cotton leaves were randomly observed by experienced exports and estimated infestation scoring of spider-mite according to equation (1) at each field.

\section{See formula 1 in the supplementary files.}

where $n$ and $p$ were the number of leaves and their infestation percentage, respectively. $i, j, I$ and etc. indicted same infestation percentage. For the unity of procedure, The estimated percentages of infestation were reported based on specific intervals including 0 for no evidence of spider-mite, 1-5 for 1$10 \%, 11-20 \%, 21-30 \%, 31-50 \%$ and $50 \% \geq$ infected leaf area, respectively. In this research, collected data from 65 cotton fields were used throughout Golestan Province; 6 ( $\mathrm{min}) * 6(\mathrm{~min})$ grid cells in the Degrees, Minutes, Seconds (DMS) coordinate system (Figure 2). These fields were measured the percentages of spider-mite involvement during a fixed time (Saturday every monitoring window). After that, distribution maps of spider-mite were spatially analyzed for 15 monitoring windows by Inverse Distance Weighted (IDW) interpolation using ArcMap/ GIS 10.6 software. The deterministic interpolator method by 'Spatial Analyst Tools' in ArcMap software package (version 10.6, ESRI, Redlands, CA) was used to draw spidermite distribution maps from the collected data. This process was performed and tried in every monitoring field located inside a cell grid.

\section{2-3-2 Correlation analysis:}

Various satellite data, such as AAL index of Sentinel-5P, LST-MODIS (Terra), NDVI-Sentinel-2, CHIRPS and ET-MODIS, were assessed as main factors (independent) on spider-mite out breaking. For each window, 200 random points were extracted between an interpolation map of spider-mite (dependent) and five satellite-based parameters (Independent) by 'ee.FeatureCollection.randomPoints' by Google Earth Engine platform. The relations between five parameters and the distribution map were statistically examined using ANOVA regression analysis in SPSS (version 23).

\section{2-3-3 Spatial Autocorrelation}

Moran's Index has known the more applicable statistic for spatial autocorrelation. Global Moran's I estimate the possibility of spatial correlation at study region. The amplitude of fluctuations of the 
Moran's I values is between 1 and -1 . Positive autocorrelation (clustered) and negative autocorrelation (dispersed) in the data translates into positive and negative values of Moran's I, respectively. Random distribution of a variable (no autocorrelation) results in a value close to 0 (Overmars et al. 2003). The relationship between a pixel and its surrounding pixel was estimated by weights matrix. Therefore, a distance-based weight matrix (a threshold distance $5000 \mathrm{~m}$ ) was applied to consider "neighbors" (just non zero value) for all pixels located at a certain distance. The normal approximation for global Moran's I could be standardized to and (Legendre and Fortin 1989). The significance level of was a threshold (1.96) so that the spatial autocorrelation can be consider significant if fluctuates between 1.96 and -1.96 (Zhang and McGrath 2004). The spatial correlogram shows patterns of

spatial autocorrelation when increasing the distance between observations. The spatial correlogram is drawn by two common shapes including Moran's I or (standardized Moran's I) (Legendre and Fortin 1989) plotted in ordinate, against distances (in abscissa). Although, the standardized correlogram represented the spatial correlation distance that is the first positive peak (Zhang et al. 1998). Local Moran's I is computed to identify the locations of spatial clusters and outliers (Anselin 2010). In the Local Moran's I analysis, there are five possibilities for local spatial autocorrelation. Two types of them distinguish spatial clusters including high values surrounded by high values (High-high), and low values surrounded by low values (Low-low). Two types of them are known as outliers, including high values surrounded by low values (High-low) and low values surrounded by high values (Low-high). Finally, the last one is non-significant spatial patterns in other words spatial randomness.

\section{2-3-4 Geostatistic Method}

In the grid system, the classical Inverse Distance Weighted (IDW) interpolation method had the lowest root mean square error (RMSE) in pre-evolution (Gorgan data) than the rest of the methods used to build the abundance maps which is consistent with the results of Al-Kindi et al., (2017). The IDW method estimated values of an unknown pixel by nearby pixels predicted but restricted in the range of maximum and minimum values of true pixels. Nearest Neighbor Statistical (NNS) analysis was spatially detected statistical moth distribution including absence, random, regular, or aggregation possibility in each area (Vinatier et al. 2011).

\section{Results And Discussion}

\subsection{Spatial Pattern Analysis of Spider-mite using the Spatial Autocorrelation Analysis}

Generally, the higher Moran's I in absolute value presents the greater the spatial correlation and also, more significant spatial autocorrelation shows by the higher standardized form of Moran's I . is able to compare statically spatial patterns of different phenomenon or different calculating parameters of the same phenomenon. At the global autocorrelation, Table 2 depicted the first three windows (there was not data for spider-mite population at first window) did not show the significance correlation (random distribution) for the standardized form of global Moran's I $(\geq 1.96)$, and fourth window was at the 
significance level during June 2020. Those periods, the cotton plant did not complete canopy but at fourth window was symmetrical with the wheat harvesting calendar in Golestan province. Wheat harvesting causes huge local dust. After that, a sinusoidal pattern was shown in Global autocorrelation (randomness to aggression, vice versa) (Table 2). By beginning in August 2020 (nine and eleventh windows), study areas had faced with a spider mite out-breaking and the strongest spatial structure (Figure.3 $\mathrm{h}$, i). Descending spatial structure at tenth, thirteen and fourteen windows could be related to pesticide application at cotton fields.

Table 2. Spatial global autocorrelation of spider mite population at monitoring programs, Dispersed [ $Z(I) * *<-2.58 ;-2.58 \leq Z(I)^{*} \geq-1.96 ; p$-value $\left.=0.1,-1.96 \leq Z(I) \geq-1.65\right]$, Random [-1.96 $\left.\leq Z(I)^{n s} \geq-1.65\right]$, Clustered $[\mathrm{Z}(\mathrm{I}) \star *>-2.58,1.96 \leq \mathrm{Z}(\mathrm{I}) * \geq 2.58 ; \mathrm{p}$-value $=0.1,1.65 \leq \mathrm{Z}(\mathrm{I}) \geq-1.96]$

\begin{tabular}{|lllll|}
\hline period & Global Moran's Index & Z-score & p-value & pattern \\
\hline Window_1 & No Data & & & \\
\hline Window_2 & 0.029207 & 0.731330 & 0.464578 & Random \\
\hline Window_3 & -0.003930 & 0.107097 & 0.914712 & Random \\
\hline Window_4 & 0.247838 & 3.871930 & 0.000108 & Clustered \\
\hline Window_5 & 0.053822 & 1.018388 & 0.308494 & Random \\
\hline Window_6 & 0.043046 & 0.961567 & 0.336267 & Random \\
\hline Window_7 & 0.096227 & 1.789161 & 0.073589 & Clustered \\
\hline Window_8 & 0.076148 & 1.641488 & 0.100696 & Random \\
\hline Window_9 & 0.337405 & 6.283151 & 0.000000 & Clustered \\
\hline Window_10 & -0.009247 & -0.016164 & 0.987104 & Random \\
\hline Window_11 & 0.262986 & 6.777026 & 0.000000 & Clustered \\
\hline Window_12 & 0.217330 & 4.373817 & 0.000012 & Clustered \\
\hline Window_13 & 0.039474 & 0.991156 & 0.321610 & Random \\
\hline Window_14 & 0.042141 & 1.339547 & 0.180393 & Random \\
\hline Window_15 & 0.264988 & 5.138441 & 0.000000 & Clustered \\
\hline
\end{tabular}

Figure.S1 represent the standardized spatial correlograms of spider-mite distribution at all monitoring windows (15 windows) and the threshold distance of weight matrix where the Moran's I and the standardized Moran's I, Z(I) reached a maximum value. At first windows (May 30, 2020 - June 9, 2020), spider-mite was not observed in pilot farms. Therefore, any data was reported by local experts. In generally, the optimal distance was $10 \mathrm{~km}$ to reach maximum Moran's I for detecting local spatial pattern. Positive value of standardized Moran's I values at a distance from $5 \mathrm{~km}$ to $15 \mathrm{~km}$ indicated spatial 
clusters of similar spider-mite population at these distance ranges. The interpolation maps of spider-mite population were performed using the Inverse Distance Weighted (IDW) method by the cross-validation of parameters. Evaluation indices from cross-validation of IDW maps for all monitoring windows are given in Table 3 and Figure S2. Cross-Validation of spatial interpolation was estimated model accuracy. Common parameters which could measure errors are Mean Error (ME), Mean Absolute Error (MAE), Mean Squared Error (MSE) and Root Mean Squared Error (RMSE). RMSE which sensitive to outliers is known as an optimal model evaluator by measuring error size (Willmott 1982; Hernandez-Stefanoni and PonceHernandez 2006). The smaller RMSE showed that semivariogram parameters calculated by fitting of experimental values are suitable and geostatistical prediction works more accurate. According to interpolation maps of spider mite distribution, some regions struggled with high population density of $T$. urticae (Figure 3). The pattern of infestation of T. urticae was the temporal hot spots in central and eastern areas of Golestan province where grains were mechanized harvested with dust pollution (Figure 3 b-f). In late July, by establishing spring and summer crops (such as cotton), the pattern of $T$. urticae was changed to other regions of study areas. From the eighth window (July 21, 2020- July 29, 2020), Aqqala was showed the main area of $T$. urticae (Figure $3 \mathrm{~g}$ ). This finding was confirmed by the Agriculture Administration which named Aqqala is the niche of T. urticae at Golestan province. On fifteenth window, T. urticae population has declined sharply because of completion of the growing season of cotton and the arrival of the harvest dates (Figure $3 \mathrm{n}$ ). Spatial analysis of $T$. urticae during growing season of cotton showed ups and downs in T. urticae populations but the climatic aspects which influencing this pattern was remained hidden. Based on empirical observations, climatic variables have a significant impact on $T$. urticae population, especially Aerosol and dust in air.

Table 3. Evaluation indices of the interpolation maps (IDW) of spider-mite distribution during monitoring program 


\begin{tabular}{|lll|}
\hline period & equations & RMSE \\
\hline Window_1 & No data & \\
\hline Window_2 & $0.029 * x+0.023$ & 0.3556 \\
\hline Window_3 & $0.018 * x+0.1086$ & 0.5555 \\
\hline Window_4 & $0.035 * x+0.116$ & 0.4650 \\
\hline Window_5 & $0.063 * x+0.284$ & 0.62478 \\
\hline Window_6 & $0.035 * x+0.201$ & 0.7948 \\
\hline Window_7 & $0.0557 * x+0.209$ & 0.6404 \\
\hline Window_8 & $0.091 * x+0.161$ & 0.6792 \\
\hline Window_9 & $0.255 * x+0.102$ & 0.534 \\
\hline Window_10 & $0.0279 * x+0.239$ & 1.009 \\
\hline Window_11 & $0.066 * x+0.257$ & 0.891 \\
\hline Window_12 & $0.137 * x+0.259$ & 0.893 \\
\hline Window_13 & $0.032 * x+0.239$ & 1.054 \\
\hline Window_14 & $0.012 * x+0.25$ & 0.919 \\
\hline Window_15 & $-0.008 * x+0.071$ & 0.6030 \\
\hline
\end{tabular}

\subsection{Effect of climatic factors on Spider-mite population}

As mentioned before, until the fifth windows (Figure 3d), there was not enough canopy to establish $T$. urticae on cotton fields, after that, spider mite out-breaking was coincided with the wheat harvest and high aerosol index 0.167 on 21 June 2020. In the first three windows, study area where experienced several dusty days, faced with first $T$. urticae population peak (Figure 3d and Figure 4). Statically tight relationship between dusty days and spider mite was repeated in transition mode from the ninth and thirteenth to their next windows (w9 to w10 and w13 to w14) (Figure 4). The effect of dust or different environmental conditions on spider mites was reported by several studies (Hodek 1987; Thomas 2001; Guerena and Sullivan 2003). Results of previous studies conducted by Flint (1998) and Guerena and Sullivan (2003) supported current results. For mentioned studies also represented that the dusty conditions almost cause to increase T. urticae population on farms. According to Demirel and Cabuk (2008) finding, spider mite densities were 1.72, 1.75, 4.39 and 2.65 times higher on cotton farms in the vicinity of dirt roads than asphalt roads. Therefore removal of dust population is considering one of applicable approach in organic cotton production (Guerena and Sullivan 2003) to control T. urticae including insecticidal soaps and water washing by complete coverage. Precipitation effect which has the ability to remove dust on cotton canopies on T. urticae population presented in (Figure 5). In first windows, it could be observed a hidden aspect of rainfall on low population of $T$. urticae, because of not 
only low density canopy but also about $2.5 \mathrm{~mm} /$ day precipitation at this period. This negative relationship was repeated in the ninth and twelfth windows (approximately $2 \mathrm{~mm}$ ). Based on current result, even if rain did not fall about $2 \mathrm{~mm}$ on July 6 and 16, 2020 you would experience severe outbreaking during July 2020. The threshold precipitation level was estimated at least $2 \mathrm{~mm}$ to clean up canopy. Rao et al., (2018) evaluated the effect of environmental factors on the population dynamics of $T$. urticae in Brinjal, India ecosystem and reported a gradual increase in T. urticae population from 4.34 to 32.64 (number of mites present in $2 \mathrm{~cm}^{2}$ leaf area) in agreement with current research by increasing from 0.05 to 0.45 spider-mite scoring. According finding Rao et al., (2018) rainfall $\left(Y=19.358-1.055 X ; R^{2}=\right.$ 0.378 ) had significant negative correlation with $T$. urticae population which confirmed negative correlation in the second $\left(\mathrm{y}=-1.494 \mathrm{x}+0.3184 ; R^{2}=0.2201\right)$, ninth $\left(\mathrm{y}=-0.4616 \mathrm{x}+0.6478 ; R^{2}=0.1329\right)$ and twelfth $\left(y=-0.1428 \mathrm{x}+0.1103 ; R^{2}=0.1213\right)$ windows of the current study. The absence of precipitation when coupled with suitable temperature was introduced a main contributing environmental factor for the rise in T. urticae population by Rao et al., (2018). Evaluating the relationship between spider-mite population and the means of temperature was another part of the climate studies. The main source of temperature measurement was MODIS-LST imagery twice a day (Figure 6). We could not find a significant pattern between temperature and T. urticae population until August 2020. The significantly tight relationships were observed in the ninth $\left(\mathrm{y}=8.4748 \mathrm{x}+38.298 ; R^{2}=0.3519 ; \mathrm{P}\right.$-value $\left.=0.000\right)$, tenth (y $=7.5261 \mathrm{x}+38.43 ; R^{2}=0.1283 ; \mathrm{p}$-value= 0.008), eleventh $\left(\mathrm{y}=3.7942 \mathrm{x}+33.272 ; R^{2}=0.0859 ; \mathrm{P}\right.$-value $=$ $0.041)$, twelfth $\left(y=6.6459 x+35.306 ; R^{2}=0.1675 ; P\right.$-value= 0.004), thirteenth $\left(y=6.322 x+36.522 ; R^{2}=\right.$ 0.178 , P-value $=0.002)$ windows. In many studies, negative correlated with temperature and spider mite population were reported (Majeed et al. 2016; Fahim and El-Saiedy 2021). The current result is compatible by Fahim and El-Saiedy (2021) who reported a non-significant relationship with respect to mean temperature and T. urticae on the beginning of the season. However, there many findings from previous literatures supporting the positive relationship between the T. urticae population and temperature (Meena et al. 2013; Chauhan and Shukla 2016). Seasonal abundance of T. urticae is influenced by biotic and abiotic factors. Parasitoid and predators are known as biological factor which are suppressed by temperature and drought (Romo and Tylianakis 2013). Another climate parameter, evapotranspiration was predicted that it affects the abundance, distribution and activity of pests. Increasing evapotranspiration has potential to simulate drought conditions (Mullan et al. 2005). Correlation between spider mite population and evapotranspiration depicted a strong relationship statistically (Mean Square= $0.349 ; \mathrm{F}=21.038, R^{2}=0.637 ; \mathrm{p}$-value $=0.001$ ) in Figure 7 . The current result had similarity with finding of Litskas et al., (2019) who reported relationship between evapotranspiration and the T. urticae and its natural enemy, P. persimilis, with $R^{2} 0.46$ and 0.60 , respectively. Since that, all climate factors induced their effects to the plant, NDVI is could support a correlation with spider mite population. During monitoring windows, we observed a negative and positive relationship between NDVI and spider mite scoring. There was positive correlation between increasing NDVI and T. urticae population until the tenth window (August 2020) (Figure $8 \mathrm{a}-\mathrm{g}$ ). The fifth and sixth windows (middle of July 2020) showed significant relation $R^{2}=0.107$ ( $\mathrm{p}$-value $=0.016$ ) and $R^{2}=0.110$ ( $\mathrm{p}$-value $\left.=0.015\right)$, respectively. Beginning in August, 2020, the type of relationship was shifted to negative especially ninth and thirteenth windows 
with $R^{2}=0.273$ ( $\mathrm{p}$-value $=0.000$ ) and $R^{2}=0.139$ ( $\mathrm{p}$-value= 0.006$)$, respectively. This phenomenon was interpreted that by enhancing of cotton canopy, T. urticae had opportunity to establish their communities. After that, negative correlations were due to harmful effect of $T$. urticae population on severity NDVI decreasing (Figure 8 ). The NDVI decreasing created by T. urticae was confirmed by numerous studies which assess T. urticae population or their damages (Lan et al. 2013; Martin et al. 2015; Martin and Latheef 2017). During multi-temporal NDVI series was observed severe reduction on the eleventh window (3-11 August, 2020) because of high density of aerosol index and low rainfall (Figure $8 \mathrm{j}$ ).

\section{Conclusion}

We found that $T$. urticae had diverse responses to the climatic factors. In a pre-judgment at the beginning of study, among of climatic factors, aerosol index or dusty days was predicted severity affect to increase the spider mite density on monitoring fields. But evapotranspiration was exactly synched with $T$. urticae dynamic population. Indeed, our findings aerosol index sentinel-5 and MODIS-evapotranspiration have suitable potential to predict spider mite population with high temporal resolution. Studying these drivers offers a realistic view of what exports design accurate model under a regime of climate change.

\section{Declarations}

Funding: The author received no specific funding for this work

Conflicts of interest/Competing interests: The authors have declared that no competing interests exist

Availability of data and material: There was in supplementary data

Code availability: There was in supplementary code

Authors' contributions: It is not applicable

Ethics approval: It is not applicable

Consent to participate: It is not applicable

Consent for publication: It is not applicable

\section{References}

Ahmed M, Mamun MSA, Hoque MM, Chowdhury RS (2012) Influence of weather parameters on Red spider mite- A major pest of Tea in Bangladesh. SUST J Sci Technol 19:47-53

Al-Kindi KM, Kwan P, Andrew N, Welch M (2017) Impact of environmental variables on Dubas bug infestation rate: A case study from the Sultanate of Oman. PLoS One 12:e0178109. doi:

10.1371/journal.pone.0178109 
Allen RG (1996) Assessing Integrity of Weather Data for Reference Evapotranspiration Estimation. J Irrig Drain Eng 122:97-106. doi: 10.1061/(ASCE)0733-9437(1996)122:2(97)

Anselin L (2010) Local Indicators of Spatial Association-LISA. Geogr Anal 27:93-115. doi: 10.1111/j.1538-4632.1995.tb00338.x

Brown S, Kerns DL, Gore J, et al (2017) Susceptibility of twospotted spider mites ( Tetranychus urticae ) to abamectin in Midsouth cotton. Crop Prot 98:179-183. doi: 10.1016/j.cropro.2017.04.002

Chauhan RK, Shukla A (2016) Population dynamics of two spotted spider mite, Tetranychus urticae Koch on French bean (Phaseolus vulgaris L.). Int J Plant Prot 9:536-539. doi: 10.15740/HAS/IJPP/9.2/536539

Demirel N, Cabuk F (2008) Population Trends of Two Spotted Spider Mite, Tetranychus urticae Koch (Acari: Tetranychidae) on Cotton Nearby Soil and Asphalt Road. J Entomol 5:122-127. doi: 10.3923/je.2008.122.127

Fahim SF, El-Saiedy E-SM (2021) Seasonal abundance of Tetranychus urticae and Amblyseius swirskii (Acari: Tetranychidae and Phytoseiidae) on four strawberry cultivars. Persian J Acarol 10:191-204. doi: 10.22073/pja.v10i2.63667

Farr TG, Rosen PA, Caro E, et al (2007) The Shuttle Radar Topography Mission. Rev Geophys 45:RG2004. doi: $10.1029 / 2005 R G 000183$

Flint ML (1998) Pests of the Garden and Small Farm. A Grower's Guide to Using Less Pesticide, 2nd Editio. UC Division of Agriculture and Natural Resources and University of California, Berkeley

Fraulo AB, Cohen M, Liburd OE (2009) Visible/Near Infrared Reflectance (VNIR) Spectroscopy for Detecting Twospotted Spider Mite (Acari: Tetranychidae) Damage in Strawberries. Environ Entomol 38:137-142. doi: 10.1603/022.038.0117

Funk C, Peterson P, Landsfeld M, et al (2015) The climate hazards infrared precipitation with stations-a new environmental record for monitoring extremes. Sci Data 2:150066. doi: 10.1038/sdata.2015.66

Ghasemi Moghadam S, Ahadiyat A, Ueckermann EA (2016) Species composition of tetranychoid mites (Acari: Trombidiformes: Prostigmata: Tetranychoidea) in main landscapes of Tehran and modelling ecological niche of Tetranychoidea in main climates of Tehran Province, Iran. Biol 71:1151-1166. doi: 10.1515/biolog-2016-0138

Guerena M, Sullivan P (2003) Organic Cotton Production. 24

Hernandez-Stefanoni JL, Ponce-Hernandez R (2006) Mapping the Spatial Variability of Plant Diversity in a Tropical Forest: Comparison of Spatial Interpolation Methods. Environ Monit Assess 117:307-334. doi: $10.1007 /$ s10661-006-0885-z 
Hodek I (1987) W. Helle \& M. W. Sabelis, Eds (1985). Spider mites. Their Biology, Natural Enemies and Control. Entomol Exp Appl 43:203-204. doi: 10.1111/j.1570-7458.1987.tb03606.x

Honarparvar N, Khanjani M, Forghani SHR, et al (2012) Demographic parameters of two spotted spider mite, Tetranychus urticae Koch (Acari: Tetranychidae) on cotton. Arch Phytopathol Plant Prot 45:381390. doi: $10.1080 / 03235408.2011 .587296$

Huang H, Deng J, Lan Y, et al (2018) A two-stage classification approach for the detection of spider miteinfested cotton using UAV multispectral imagery. Remote Sens Lett 9:933-941. doi:

$10.1080 / 2150704 X .2018 .1498600$

Kumral NA, Kovanci B (2005) Acarologia is proudly non-profit, with no page charges and free open access. Acarologia 45:295-301. doi: 10.1051/acarologia/20142144

Lamqadem AA, Saber H, Pradhan B (2018) Quantitative assessment of desertification in an arid oasis using remote sensing data and spectral index techniques. Remote Sens 10:. doi: 10.3390/rs10121862

Lan Y, Zhang H, Hoffmann WC, Juan D Lopez J (2013) Spectral response of spider mite infested cotton: Mite density and miticide rate study. Int J Agric Biol Eng 6:48-52. doi: 10.3965/j.ijabe.20130601.004

Legendre P, Fortin MJ (1989) Spatial pattern and ecological analysis. Vegetatio 80:107-138. doi: 10.1007/BF00048036

Litskas VD, Migeon A, Navajas M, et al (2019) Impacts of climate change on tomato, a notorious pest and its natural enemy: small scale agriculture at higher risk. Environ Res Lett 14:. doi: 10.1088/17489326/ab3313

Liu JM, Wang HW, Chang FW, et al (2016) The effects of climate factors on scabies. A 14-year population-based study in Taiwan. Parasite 23:1-7. doi: 10.1051/parasite/2016065

Majeed MZ, Javed M, Riaz MA, Afzal M (2016) Population dynamics of sucking pest complex on some advanced genotypes of cotton under unsprayed conditions. Pak J Zool 48:475-480

Margolies DC, Wrensch DL (1996) Temperature-induced changes in spider mite fitness: offsetting effects of development time, fecundity, and sex ratio. Entomol Exp Appl 78:111-118. doi: 10.1111/j.15707458.1996.tb00770.x

Martin DE, Latheef MA (2017) Remote Sensing Evaluation of Two-spotted Spider Mite Damage on Greenhouse Cotton. J Vis Exp 122:1-9

Martin DE, Latheef MA, López JD (2015) Evaluation of selected acaricides against twospotted spider mite (Acari: Tetranychidae) on greenhouse cotton using multispectral data. Exp Appl Acarol 66:227-245. doi: 10.1007/s10493-015-9903-6 
Meena NK, Pal R, Pant RP, Medhi RP (2013) Seasonal Incidence of Mite and Infuence of Pesticidal Application on Orchid Flower Production. J Plant Prot Res 53:124-127. doi: 10.2478/jppr-2013-0018

Mullan B, Porteous A, Wratt D, Hollis M (2005) Changes in drought risk with climate change. NIWA, New Zealand

Overmars KP, de Koning GHJ, Veldkamp A (2003) Spatial autocorrelation in multi-scale land use models. Ecol Modell 164:257-270. doi: 10.1016/S0304-3800(03)00070-X

Rao KS, Vishnupriya R, Ramaraju K, Poornima K (2018) Effect of Abiotic Factors on the Population Dynamics of Two Spotted Spider Mite, Tetranychus Urticae Koch and Its Predatory Mite, Neoseiulus Longispinosus (Evans ) in Brinjal Ecosystem. J Exp Zool India 21:797-800

Reisig D, Godfrey L (2006) Remote Sensing for Detection of Cotton Aphid- (Homoptera: Aphididae) and Spider Mite- (Acari: Tetranychidae) Infested Cotton in the San Joaquin Valley. Environ Entomol 35:16351646. doi: 10.1093/ee/35.6.1635

Romo CM, Tylianakis JM (2013) Elevated Temperature and Drought Interact to Reduce Parasitoid Effectiveness in Suppressing Hosts. PLoS One 8:e58136. doi: 10.1371/journal.pone.0058136

Scott WS, Catchot A, Gore J, et al (2013) Impact of Twospotted Spider Mite (Acari: Tetranychidae) Duration of Infestation on Cotton Seedlings. J Econ Entomol 106:862-865. doi: 10.1603/EC12333

Soleimany A, Grubliauskas R, Šerevičienè V (2021) Application of satellite data and GIS services for studying air pollutants in Lithuania (case study: Kaunas city). Air Qual Atmos Heal 14:411-429. doi: 10.1007/s11869-020-00946-z

Stavrinides MC, Mills NJ (2011) Influence of temperature on the reproductive and demographic parameters of two spider mite pests of vineyards and their natural predator. BioControl 56:315-325. doi: $10.1007 / \mathrm{s} 10526-010-9334-6$

Thomas C (2001) Biological control of two-spotted spider mite. Integrated Pest Management Program, Pennsylvania Department of Agriculture. In: Univ. Connect. UConn Extension, Coll. Agric. Heal. Nat. Resour. http://ipm.uconn.edu/documents/raw2/html/664.php?aid=664

Vinatier F, Tixier P, Duyck P-F, Lescourret F (2011) Factors and mechanisms explaining spatial heterogeneity: a review of methods for insect populations. Methods Ecol Evol 2:11-22. doi: 10.1111/j.2041-210X.2010.00059.x

Wermelinger B, Oertli JJ, Baumgärtner J (1991) Environmental factors affecting the life-tables ofTetranychus urticae (Acari: Tetranychidae) III. Host-plant nutrition. Exp Appl Acarol 12:259-274. doi: 10.1007/BF01193472 
Willmott CJ (1982) Some Comments on the Evaluation of Model Performance. Bull Am Meteorol Soc 63:1309-1313

Zhang C, McGrath D (2004) Geostatistical and GIS analyses on soil organic carbon concentrations in grassland of southeastern Ireland from two different periods. Geoderma 119:261-275. doi:

10.1016/j.geoderma.2003.08.004

Zhang C, Zhang S, He J (1998) Spatial Distribution Characteristics of Heavy Metals in The Sediments of Changjiang River System -Spatial Autocorrelation And Fractal Methods. Acta Geogr. Sin. 53:87-96

\section{Figures}

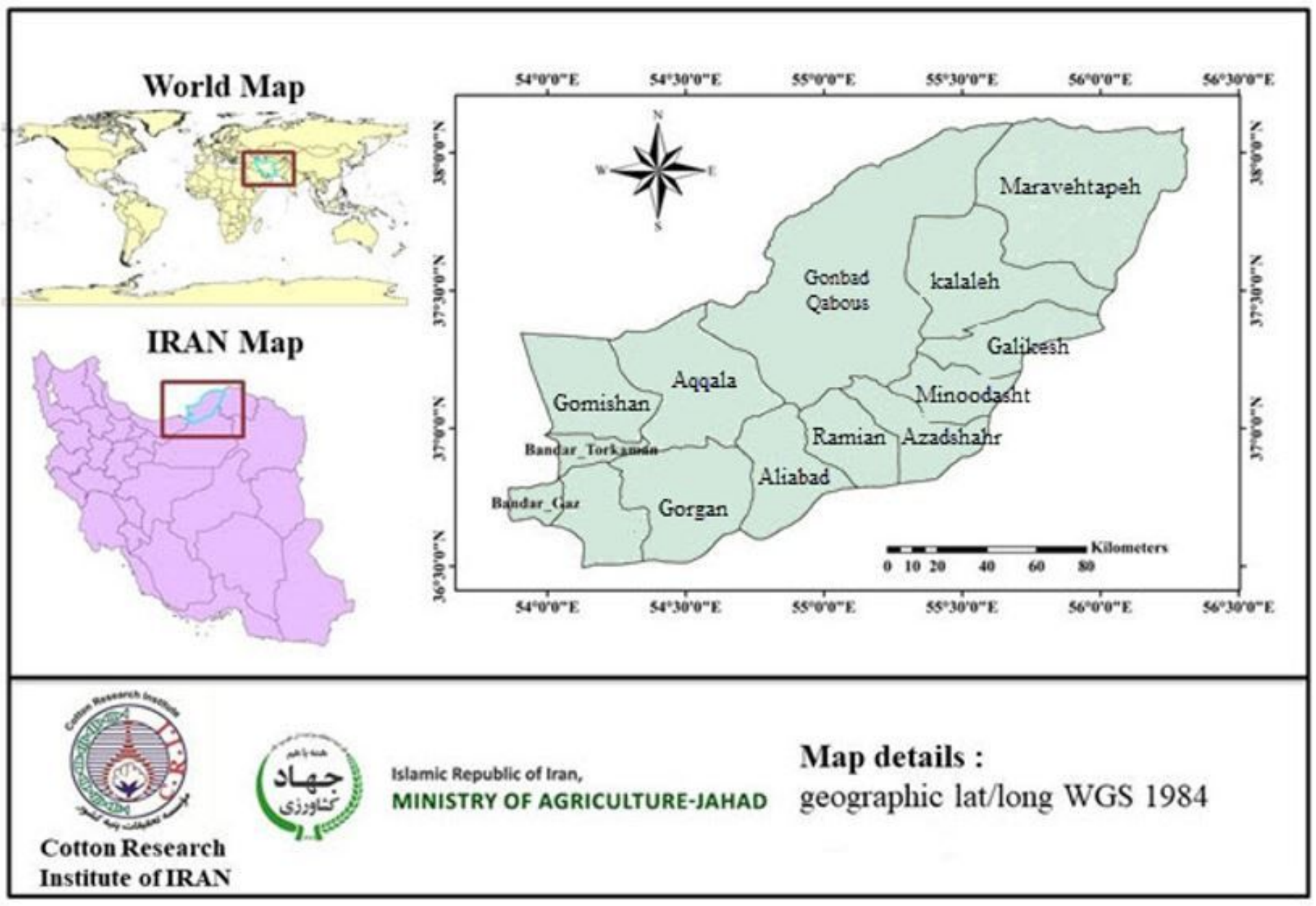

\section{Figure 1}

Location of the study area on the world (the Golestan province, Iran). 


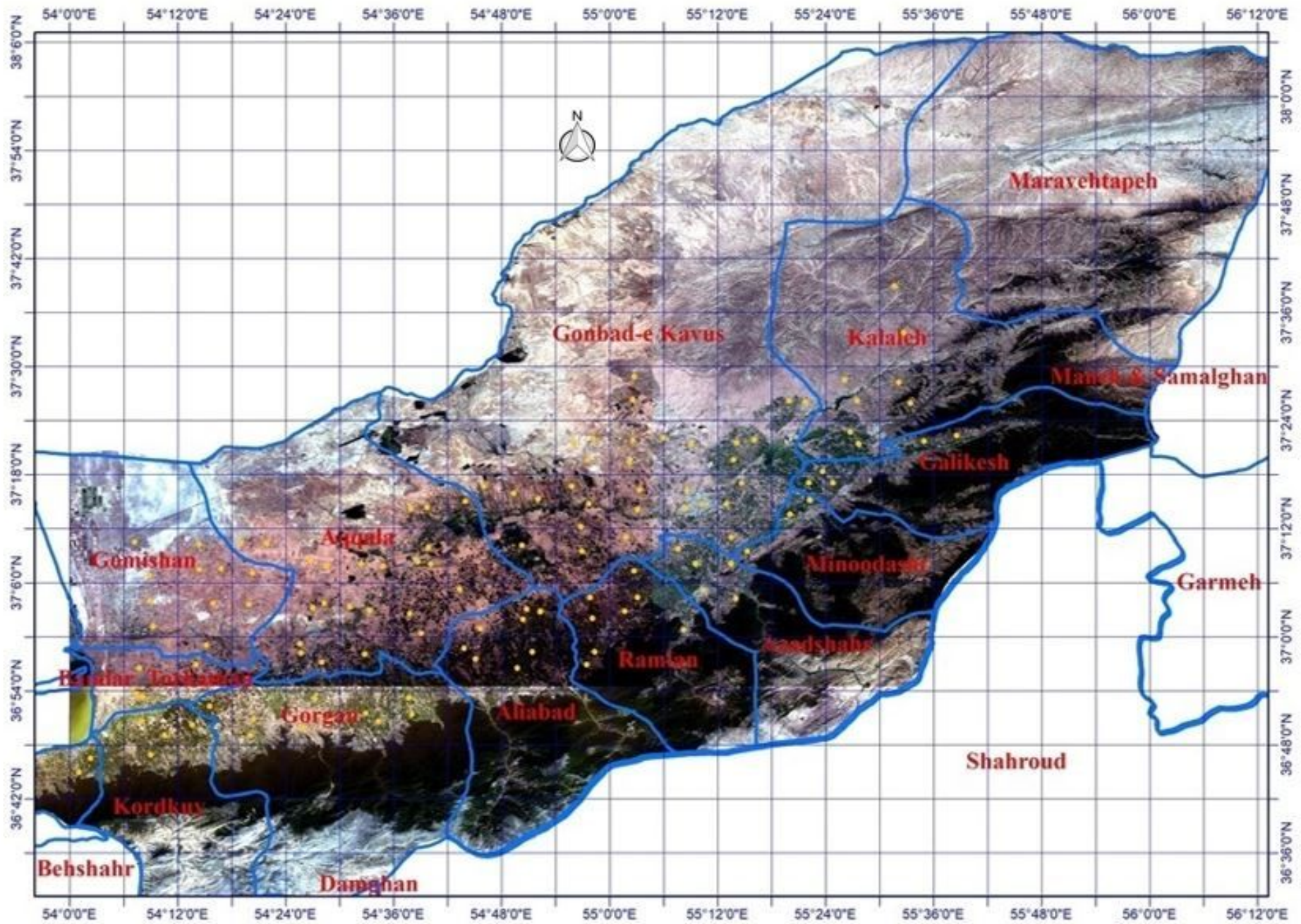

Figure 2

Distribution of spider-mite throughout Golestan Province; $6(\mathrm{~min}) * 6(\mathrm{~min})$ grid cells in the DMS coordinate system (yellow points are monitoring field) 

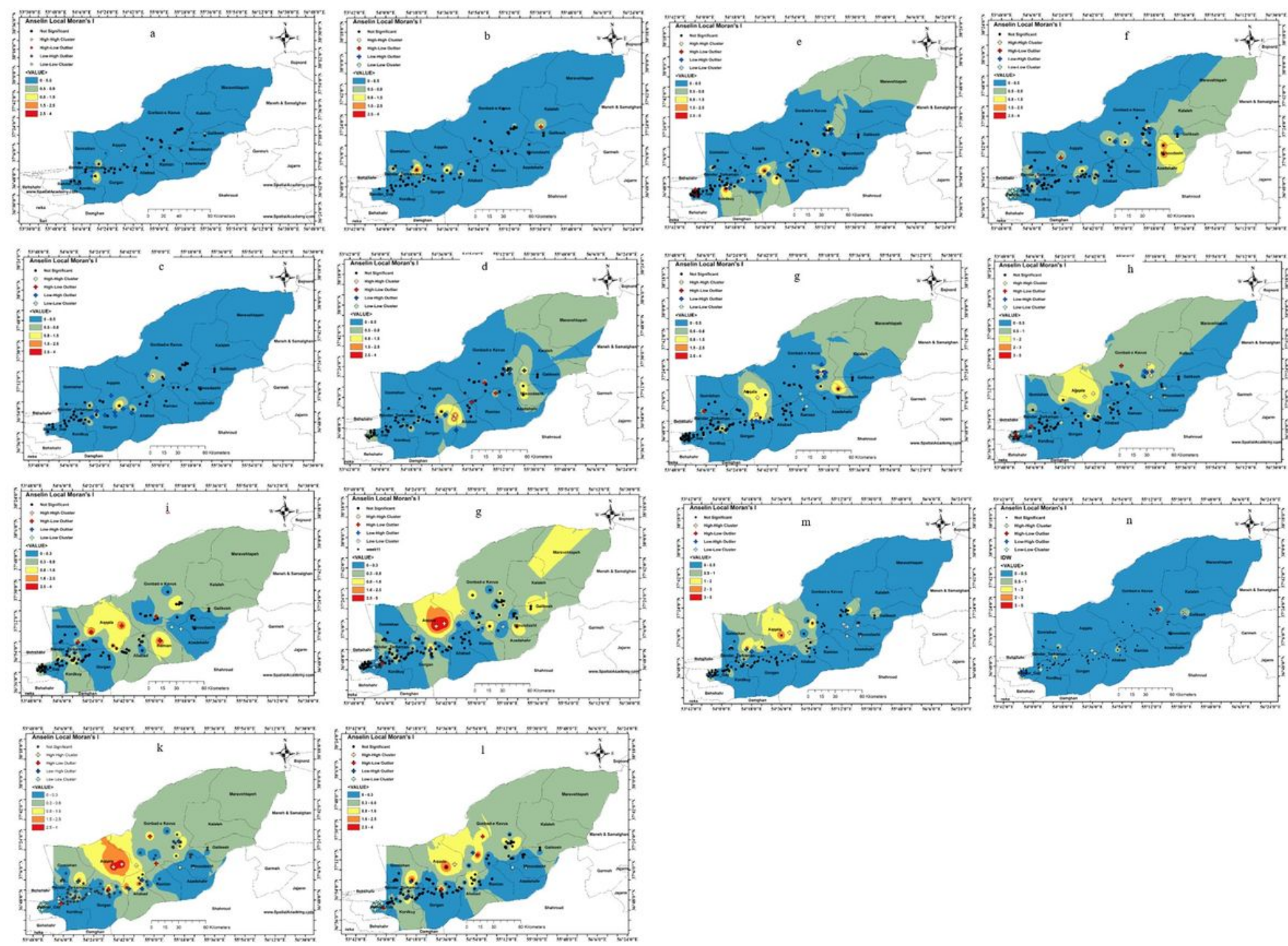

\section{Figure 3}

Distribution maps of spider mite based on IDW model during monitoring windows, a-n are the sequence windows form June 9, 2020 to September 17, 2020. (First window, May 30 to June 9 was not spider mite population data) 


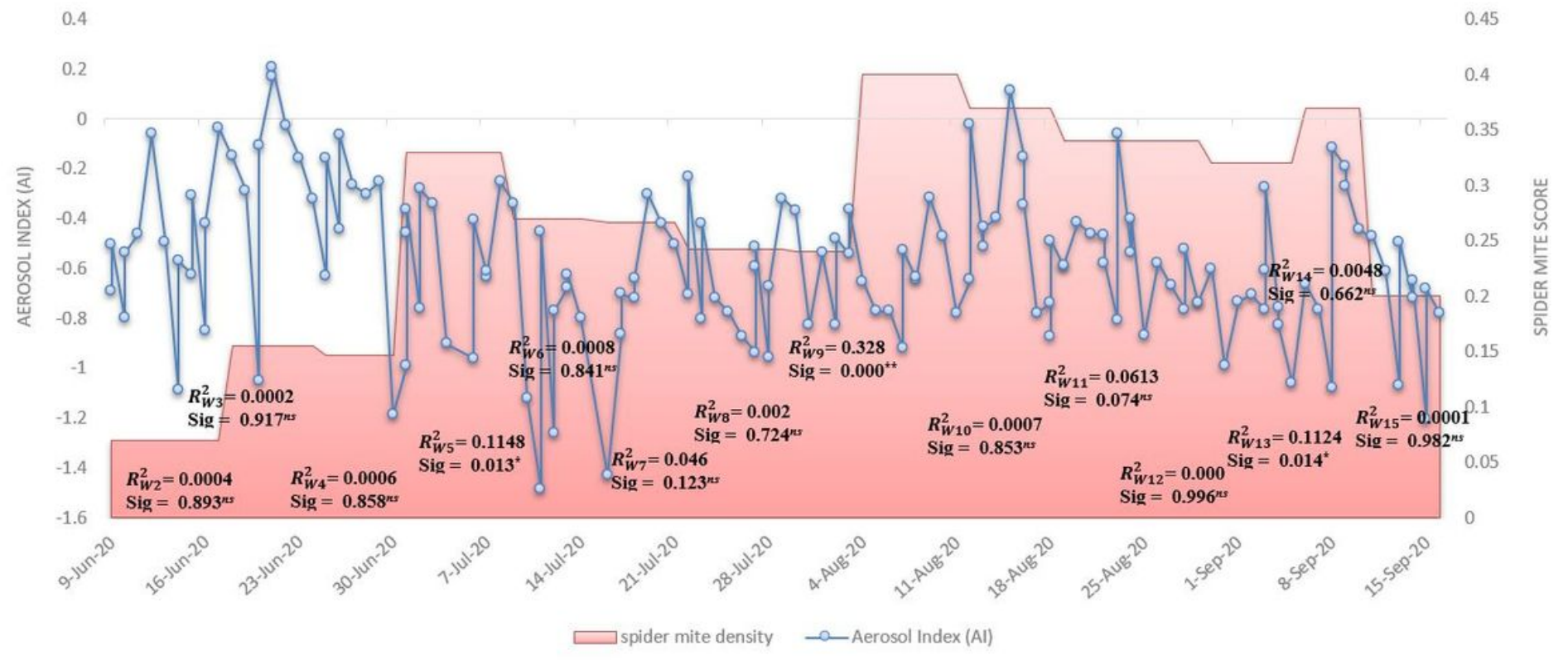

Figure 4

The relationship between UV Aerosol Index extracted from Sentinel-5 imagery and spider mite population (mean score of each window) form June 9, 2020 to September 17, 2020. (First window, May 30 to June 9 was not spider mite distribution data)

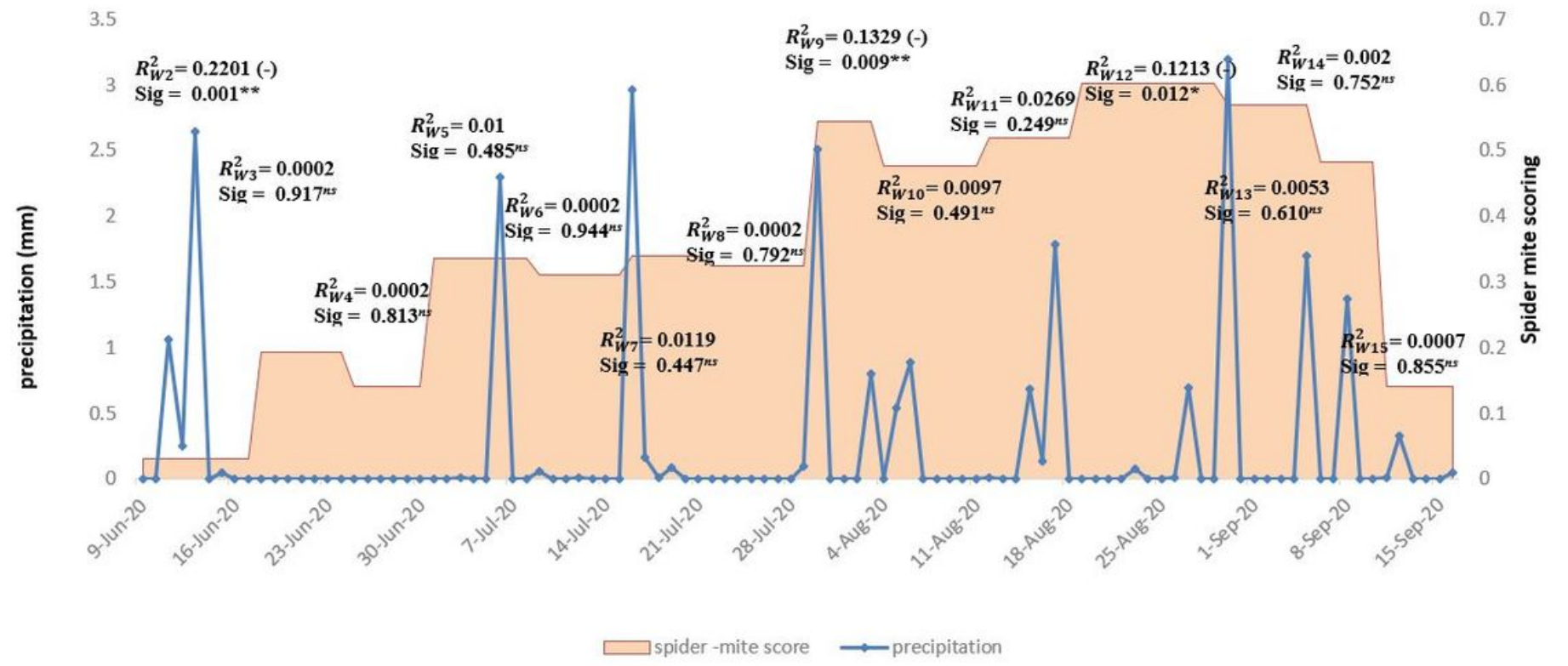

\section{Figure 5}

The relationship between daily CHIRPS-precipitation and spider mite population (mean score of each window) form June 9, 2020 to September 17, 2020. (First window, May 30 to June 9 was not spider mite distribution data) 


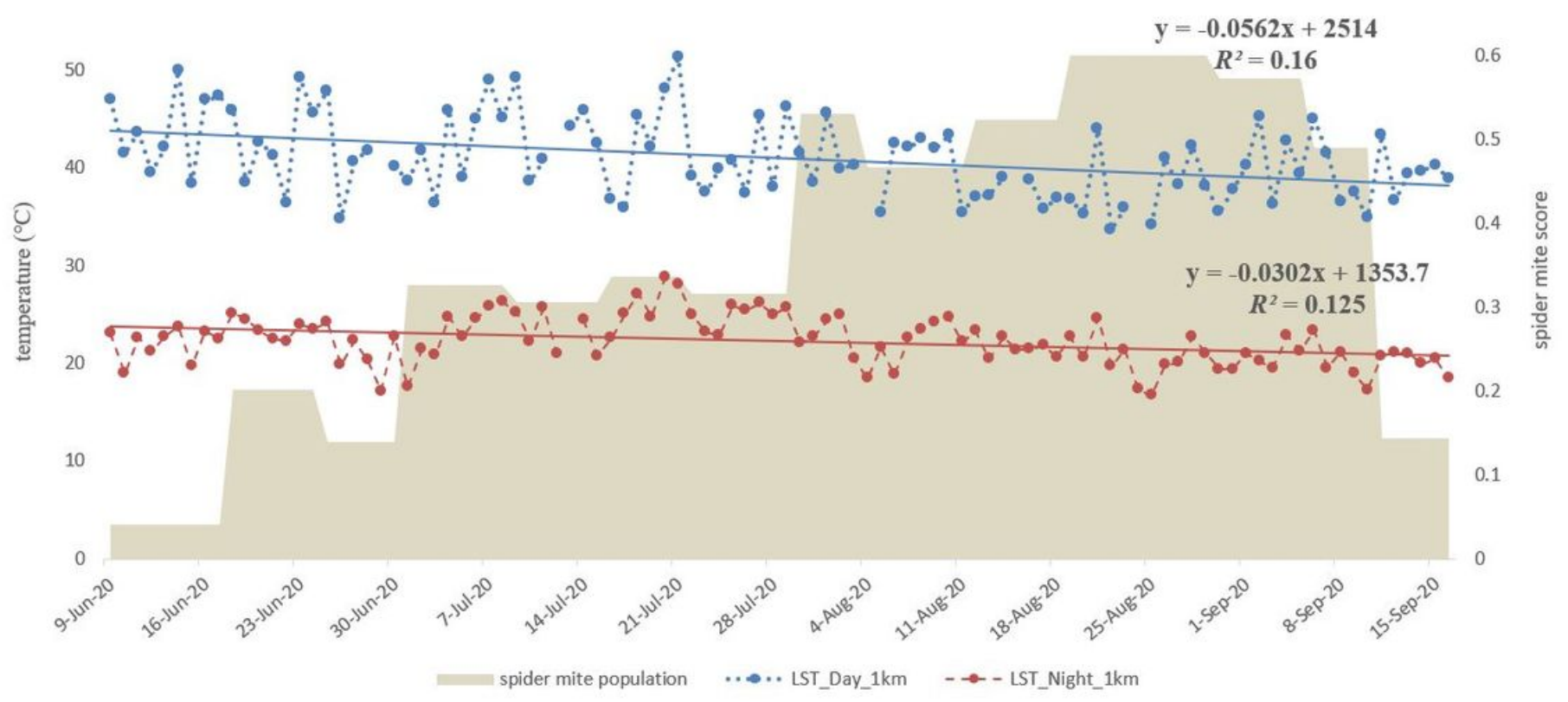

\section{Figure 6}

The relationship between daily Land Surface Temperature and spider mite population (mean score of each window) form June 9, 2020 to September 17, 2020. (First window, May 30 to June 9 was not spider mite distribution data), ... and -- are Day and night LST, respectively. 


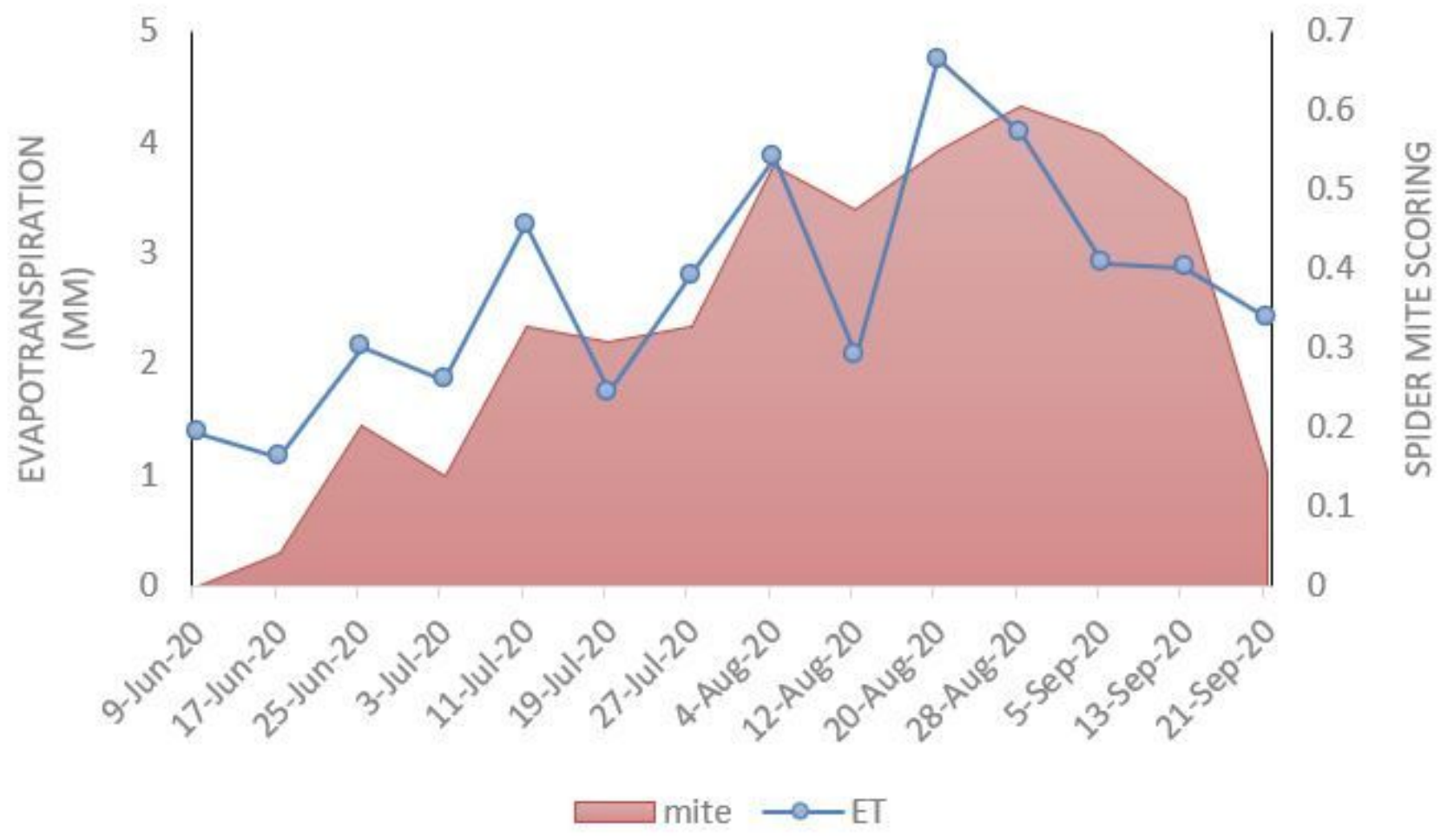

Figure 7

The relationship between MODIS-Evapotranspiration and spider mite population (mean score of each window) form June 9, 2020 to September 17, 2020. (First window, May 30 to June 9 was not spider mite distribution data). 

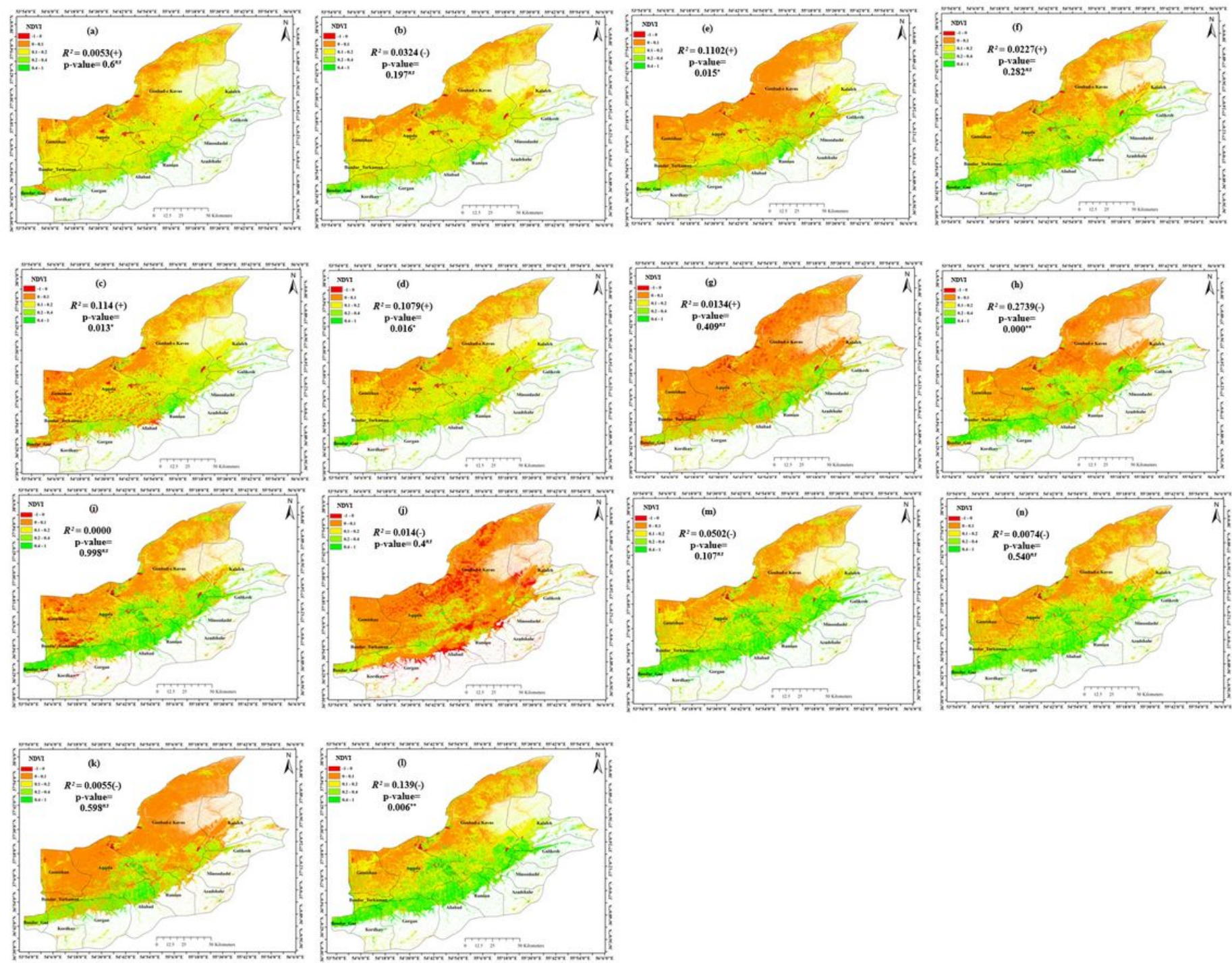

\section{Figure 8}

The relationship between NDVI (10 m) provided form Sentinal-2 and density of spider mite during monitoring windows based on ANOVA for linear regression. The alphabetical letters indicate of the sequence windows form June 9, 2020 to September 17, 2020. (First window, May 30 to June 9 was not spider mite distribution data).

\section{Supplementary Files}

This is a list of supplementary files associated with this preprint. Click to download.

- Supplementryfigure.docx 